\title{
A review of the book 'Cold-blooded Vertebrates in Nicaragua and its Regional Development' by Ivo Pavlík and Miguel Ángel Garmendia Zapata
}

\author{
Sándor Némethy \\ University of Gothenburg \\ sandor@,conservation.gu.se
}

\begin{abstract}
This paper summarizes the views of the author on the new book 'Cold-blooded Vertebrates in Nicaragua and its Regional Development' by Ivo Pavlík and Miguel Ángel Garmendia Zapata.
\end{abstract}

Keywords - cold-blooded vertebrates, Nicaragua, regional development

Located in the tapering isthmus of Central America, Nicaragua is a country where culture, traditions, and biodiversity merge together on a daily basis. This book was conceived through the close cooperation of professors Ivo Pavlík of Mendel University, Czech Republic and Miguel Ángel Garmendia Zapata, academic and biologist from National Agrarian University, Nicaragua based on their previously published monograph, which focused on invertebrates from the Carazo Region (Pavlik and Garmendia, 2017; Pavlik and Garmendia, 2018).

This book (Pavlik and Garmendia, 2020) gives a truly interdisciplinary summary of the scientific research activities of both authors including observations, local surveys and studies of extensive local and global literature sources. The number of cited literature sources significantly exceeds the usual range of such monographs.

Authors' descriptions are focused on cold-blooded vertebrates that were found in farm called "Finca La Reserva", in Carazo Department, a scientific and educational field-base that belongs to Mendel University in Brno since 2011. The Finca La Reserva is mainly visited by academics and students from the Faculty of Regional Development and International Studies and Faculty of Forestry and Wood Technology (Mendel University in Brno, Czech Republic). Furthermore, several animals' species were observed in different places in the Pacific and Atlantic coasts, in different lowlands, volcanoes and in Central Cordillera Range.

Cold-blooded vertebrates are an important element in the regional development of Nicaragua. It was authors' interest to describe a small portion of the biodiversity of Nicaragua, paying special attention to common cold-blooded vertebrates that were encountered during several visits from 2014 to 2018. These species are economically important for local people, as a source of food, pet or touristic attraction. Some of these species (i. e. iguana) are often boiled whole in salty and spicy water; they are popular local food. Locals find these animals as very pleasant addition to their diet, which is otherwise poor in animal protein. Important, that some of these animal species (i. e. turtles) are illegally hunted and nests robbed of eggs even though this increases their risk of extinction (Alther and Lameter, 2020). This kind of wildlife trafficking is strictly prohibited by EU legislation. ${ }^{1}$ The names of observed cold-blooded animals' species are

${ }^{1}$ EU Commission (2016): EU Action Plan Against Wildlife Trafficking; COM (2016) 87 final; EU Commission: Brussels, Belgium, 2016; p. 28. 
presented in Czech, Latin and English using the publicly available database "BioLib" https://www.bio-lib.cz and other resources with Spanish names. Local Nicaraguan Spanish names are also provided by deep knowledge of rural and remoted areas in different parts of Nicaragua.

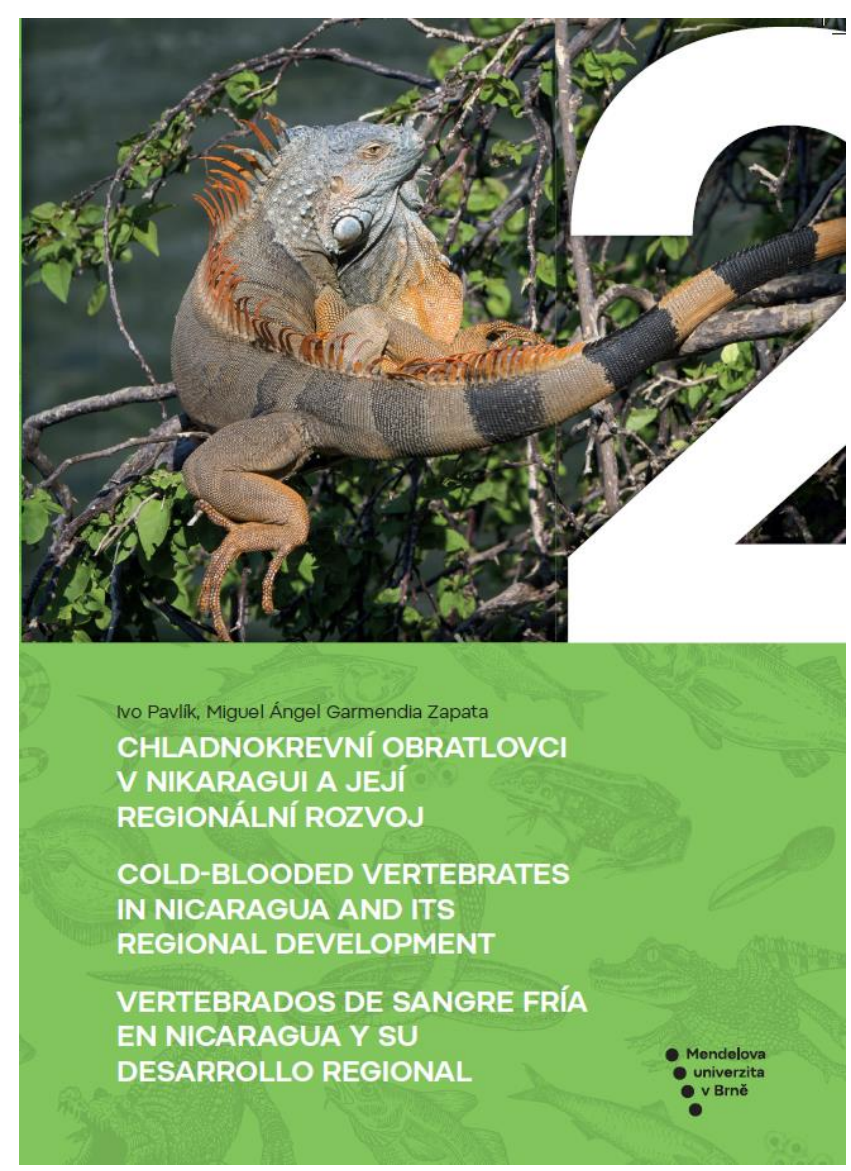

Title page of 'Cold-blooded Vertebrates in Nicaragua and its Regional Development' by Ivo Pavlík and Miguel Ángel Garmendia Zapata.

In this follow-up study, the authors continue their research, focusing on the fauna in Nicaragua, the second poorest country in Latin America after Belize. Nicaragua however, is considered a unique biogeographical area. In addition to the interesting geographical data, this book is also a rich source of information on the health risks associated with these animals, including zoonotic diseases transmitted between animals and humans (Monath, 2013; Vasícková and Pavlík, 2010; Hubálek and Rudolf, 2010) and sapronotic (soil-borne) diseases transmitted from soil to humans (Kuris et al. 2014; Hubálek and Rudolf, 2010;). These are areas of research that prof. I. Pavlik has been focusing on for a long time. The book provides a thorough description of the poor sanitary conditions and the failures of the health system in Nicaragua (Vargas-Palacios et al. 2018), including severe deficiencies in

${ }^{2}$ References listed here (apart from the previous works of the authors) are only illustrative examples of earlier research food storage due to lack of cool food storage facilities, lack of awareness of health risks, and extreme poverty.

The authors also discuss conservation issues facing coldblooded vertebrates (iguanas, fish, turtles, crocodiles and snakes) which are sold in markets, and are commonly consumed by locals. However, these animals constitute potential health risks for locals and visiting tourists not only in cities but also in rural areas including beeches.

Although there is a vast number of scientific works dealing with cold blooded vertebrate ecology, this kind of holistic and system-based approach integrating ecological, social, economic and cultural issues from a historical and evolutionary viewpoint is unique or, at least, very rare.

I am sure that this excellent scientific work, with its many detailed photographs, holistic approach and rich literature references will be useful not only for professionals dealing with issues regarding public health and medicine but also for students, academics, travellers, and tourists.

\section{ACKNOWLEDGEMENTS}

The creation of this professional book was supported by the project IP3.3 2017 (academic trip) of the Institutional Plan of Mendel University in Brno in 2017. Numerous photographs were taken within the NIKAZAM project (CZ.1.07 / 2.4.00 / 17.0028), study literature was taken within the IGA FRRMS projects No. 12/2015 and SUMCULA (2017-1-SE01KA203-034570).

\section{REFERENCES ${ }^{2}$}

Alther, S. and Lameter, K. (2020): The Rush for the Rare: Reptiles and Amphibians in the European Pet Trade. Animals 2020, 10(11), 2085. DOI:

DOI: $\underline{10.3390 / \text { ani10112085 }}$

Hubálek Z., Rudolf I. (2010): The Infection Process in Zoonoses and Sapronoses. In: Microbial Zoonoses and Sapronoses. Springer, Dordrecht.

DOI: $10.1007 / 978-90-481-9657-94$

Kuris, A. M., Lafferty, K. D. and Sokolow, S. H. (2014): Sapronosis: a distinctive type of infectious agent. Trends Parasitol. (8):386-93.

DOI: $\underline{10.1016 / \text { j.pt.2014.06.006 }}$

Monath, T. P. (2013): Vaccines against diseases transmitted from animals to humans: A one health paradigm. Vaccine. 2013 Nov 4; 31(46): 5321-5338.

DOI: $10.1016 /$ j.vaccine.2013.09.029

Pavlík, I., Garmendia, M. Á. Z., 2017. Non-vertebrates in Regional Development in Nicaragua: Region Carazo. Part 1.

done in some of the key topics. The book contains an extraordinary, vast reference base in all relevant subject areas. 
Mendel University in Brno, Czech Republic, $1^{\text {st }}$ ed. ISBN 978-80-7509-523-7. pp. 150 (in Czech, English and Spanish)

Pavlík, I., Garmendia, M. Á. Z., 2018 Non-vertebrates in Regional Development in Nicaragua: Region Carazo. Invertebrados en el Desarrollo Regional de Nicaragua: Región Carazo. Part 2. Mendel University in Brno, Czech Republic, $1^{\text {st }}$ ed. ISBN 978-80-7509-524-4. pp. 188 (in Czech, English and Spanish).
Pavlík, I., Garmendia, M. Á. Z., 2020 Cold-blooded Vertebrates in Nicaragua and its Regional Development. Part 2. Mendel University in Brno, Czech Republic, $1^{\text {st }}$ ed., ISBN 978-80-7509-524-4, 2018, pp. 188 (in Czech, English and Spanish).

Vasícková P, Pavlík I. (2010) Zoonoticky potenciál viru hepatitidy E [Zoonotic potential of the hepatitis E virus]. Klin Mikrobiol Infekc Lek. 2010 Feb;16(1):18-21. Czech. PMID: 20401833.

(C) 2020 by the author(s). This article is an open-access article distributed under the terms and conditions of the Creative Commons Attribution (CC BY) license (http://creativecommons.org/licenses/by/4.0/). 